\title{
Corporate Governance and Earnings Management: A Study of Vietnamese Listed Banks*
}

\author{
Quoc Thinh TRAN ${ }^{1}$, To Trang LAM ${ }^{2}$, Chi Danh LUU ${ }^{3}$
}

Received: August 01, 2020 Revised: October 26, 2020 Accepted: November 05, 2020

\begin{abstract}
Earnings management is a matter of concern for organizations because it affects the interests of stakeholders. This reduces the quality of information on financial statements of the organizations when the organization performs earnings management behavior. The objective of the article is to examine the impact of corporate governance on earnings management of all Vietnamese listed banks from 2015 to 2019. The article uses time-series data and ordinary least square (OLS) with Eviews 10.0 software to test the regression model. The agency and asymmetry information theory is used to explain the relationship between corporate governance and earnings management. The study results show that two variables - the foreign members of the board of directors and audit committee - have an opposite effect on earnings management behavior of Vietnamese listed banks. Therefore, the managers of listed banks need to raise awareness to express responsibility for honest and reasonable information on the financial statements. This creates trust and credibility for stakeholders. Moreover, Central bank of Vietnam should monitor regularly and enforce strict sanctions to limit earnings management behavior of listed banks. This contributes to improving the quality of accounting information in the Vietnamese banking sector to meet the trend of international economic integration.
\end{abstract}

Keywords: Board Size, Corporate Governance, Earnings Management, Listed Banks, Vietnam

JEL Classification Code: G21, G34, G41, M42

\section{Introduction}

Gordon (1964) argued that earnings management behavior (EMB) is the act of adjusting earnings through flexibility in the choice of accounting policies and estimates, but ensuring compliance with current accounting regulations. EMB

\footnotetext{
*Acknowledgements:

The authors would like to thank some experts of the Central bank of Vietnam and some leaders of Vietnamese commercial banks for their advice and support in this project.

${ }^{1}$ First Author and Corresponding Author. Associate Professor, Faculty of Accounting and Auditing, Industrial University of Ho Chi Minh City, Vietnam [Postal Address: 86 Nguyen Hong Street, Ward 1, Go Vap District, Ho Chi Minh City, 70000, Vietnam]

Email: tranthinhktkt@gmail.com

${ }^{2}$ Lecturer, Faculty of Law, Ho Chi Minh City Open University, Vietnam. Email: trang.lamt@ou.edu.vn

${ }^{3}$ Lecturer, Faculty of Accounting and Auditing, Van Lang University, Ho Chi Minh City, Vietnam. Email: tsluuchidanh@gmail.com

(c) Copyright: The Author(s)

This is an Open Access article distributed under the terms of the Creative Commons Attribution Non-Commercial License (https://creativecommons.org/licenses/by-nc/4.0/) which permits unrestricted non-commercial use, distribution, and reproduction in any medium, provided the original work is properly cited.
}

affects the quality of information disclosed on the financial statements of organizations (Schipper, 1989). Whether this behavior is negative or positive will depend on the purpose of chief executive officers (CEOs) when the execution is to gain personal benefits or to avoid undue negative effects on corporate values. This will promote business performance in the future (Scott, 2009).

EMB affects the interests of stakeholders, which mainly include the board of directors (Board), CEOs and investors. This will affect the quality of information disclosed on the financial statements of organizations and it affects the interests of information users (Schipper, 1989). Board always controls these behaviors through regulations, while the CEOs apply accounting policies to adjust information appropriately. This leads to conflicts between related parties over economic interests ( $\mathrm{Li}$, et al., 2017). Board uses a number of tools including an audit committee to monitor information, but the CEOs can use profitability techniques to beautify the financial statements and conceal weaknesses in the business results of enterprises (Leuz et al., 2003).

In Vietnam, EMB has been of interest to government regulators to control the quality of information. Recently, 
the Vietnamese state agency has made some amendments to the provisions of the Law on credit institutions (2017) and the Law on enterprises (2020) to conform to international standards, including corporate governance (CG) and specific regulations on accounting policies, as well as presentation and disclosure of companies (National assembly of Vietnam, 2017; 2020). In the Vietnamese banking sector, EMB is still implemented by a number of commercial banks due to pressures on competition and economic indicators (Tran \& Tran, 2020; Tran et al., 2020). According to some experts in the State securities commission of Vietnam, the situation of EMB in listed companies still occurs. This affects the confidence of investors and stakeholders (Nguyen \& Phan, 2020). However, the information quality of the commercial bank and listed banks remains different because listed banks require information disclosure in accordance with the regulations of the State securities commission of Vietnam. Therefore, in order to have an overarching view of EMB, this research examines the subjects as listed banks. In addition, some previous studies of Vietnam looked at the impact factors related to financial ratios and ownership structure, this research cares about factors of CG. Furthermore, compared to previous studies, this research has focused on EMB as measured on the basis the provision expense ratio for bad debt because the banking sector in Vietnam has had many fluctuations in bad debt in the last five years so there is a risk of EMB arising from these listed banks.

\section{Literature Review}

CG is the internal rules of an organization to control the activities of the company. This is to harmonize the relationship between the Board, CEOs and the shareholders of a company as well as related parties (Saiful, 2018). Fitri et al. (2018) argued that CG is the process of controlling the activities of the organization to help provide transparent information. This will bring the highest benefit to shareholders. Siyanbola et al. (2019) assumed that $\mathrm{CG}$ is a system through which a company is directed and controlled the activity. Responsibilities of the members of the Board are to build strategic goals, provide the assurance of effective strategic management, and supervise managers in business operations. CG is the regulations that are run in the organization but on a consistent basis with the provisions of the law (OECD, 2015). Hillman and Dalziel (2003) considered that $\mathrm{CG}$ is the management and supervision of the Board through the provision of financial resources to Board in order to improve economic efficiency for business operations.

Healy and Wahlen (1999) stated that EMB is made by CEOs to guide investors' decisions according to his subjective will. Beneish (2001) identified EMB as a deliberate intervention to provide financial information for financial decision-making by investors and stakeholders. EMB can be a positive goal that will contribute to enhancing the potential value of the business (Tangjitprom, 2013). Roychowdhury (2006) considered EMB is to make adjustments to the normal operating level of the firm to achieve certain objectives and to make stakeholders believe these results. Bruns and Merchant (1990) said that CEOs implement EMB to benefit from salary and dividend policy of the company. CEOs are under great pressure from the economic targets to be met from the Board so they can also implement EMB to ensure previous commitments on the business situation of the enterprises (Graham, Harvey \& Rajgopal, 2005). Cornett et al. (2009) claimed that the EMB is referred to issues including implementing discount policies or negatively loosening payment terms in order to increase revenue; cutting down on fixed costs such as research and development costs, sales and administration costs, and maintenance costs so that the cost of goods sold can be reduced and thereby increasing the accounting profit of the business.

The theories related to the factors of CG affecting EMB have been recognized by previous studies including two fundamental theories such as the agency theory and an asymmetry information theory (Olaoye \& Adewumi, 2018; Osemene et al., 2018; Saiful, 2018; Sadjiarto et al., 2019; Siyanbola et al., 2019; and Tran \& Tran, 2020). Agency theory was first developed by Jensen and Meckling (1976). Accordingly, the agents will perform some work on behalf of the principals through a contract between the parties. The parties want to maximize their interests so a conflict of interest always exists in this relationship (Saiful, 2018). Contrary to the owner's expectations, the CEOs may perform acts for personal gain rather than for the benefit of the business (Siyanbola et al., 2019). Moreover, an asymmetric information theory is mentioned by Akerlof (1970). According to Akerlof, an asymmetric information phenomenon occurs when one party has less information or has inaccurate information than the partner. The less informed party makes inaccurate decisions and at the same time, the more informed party will also act detrimentally to the counterpart. An asymmetric information between financial report makers and people wishing to use information may arise for the sake of economic interests. This disadvantage usually belongs to investors when they receive less information than publishers (Tran \& Tran, 2020). CEOs can induce adverse choices for shareholders by intentionally hiding material information because CEOs know more informed about the business (Chan et al., 2008).

There are many studies about EMB, but they mainly focus on enterprises, while the banking sector has limitations. Typically, Cornett et al. (2009) studied the relationship between CG and EMB in 46 United States banks in the period from 1994 to 2002 . The article uses 
OLS to test the model. The regression results show that the independent members of Board and the audit committee have a negative impact on the EMB, while Board chairperson duality is positive with the EMB. Li et al. (2017) examined the factors affecting EMB of 6,132 observations of firms from 2009 to 2014. The article uses OLS to verify. The results find that the audit committee of Big4 has an opposite effect on EMB, while the variable of the independent members of Board has no effect on EMB. Olaoye and Adewumi (2018) checked on the relationship between CG and EMB at Nigerian listed commercial banks over a 10-year period from 2006 to 2015 . OLS is also used to test. The regression results indicate that the variable of the independent members of Board has a negative effect on the EMB, while the Board size and audit committee have no effect on the EMB.

Osemene et al. (2018) researched the factors affecting EMB of 14 commercial banks listed in Nigeria from 2011 to 2016. The regression testing is considered in the model. The regression results show that the variable of the number of the female directors on Board has a negative impact on EMB, while Board size has no effect on EMB. Fitri et al. (2018) considered the influence of CG on EMB of 30 listed commercial banks in Indonesia from 2012 to 2016. OLS is used by to test. Research results explore that the variable of the independent members of Board has a negative impact on EMB while the audit committee has no effect on EMB. Saiful (2018) studies on the relationship between $\mathrm{CG}$ and EMB of 27 conventional commercial banks and 10 Islamic listed commercial banks listed from 2012 to 2016 . The multivariate regression is used to test the model. The results show that the audit committee and the independent members of Board have the same impact with the EMB, but the Board size has no effect on the EMB. Sadjiarto et al. (2019) studied the impact of CG on EMB of 45 Indonesian listed commercial banks in the period 2010-2017. The article uses OLS to test the model. The regression results find that the variable of the independent members of Board has a positive impact on the EMB. Siyanbola et al. (2019) examined the impact of CG on EMB of ten banks in Nigerian from 2008 to 2017. The multivariate regression is used to check. The results show that the variable of number of foreigner members of Board has a positive effect on EMB, while Board size and the independent members of Board have no effect on EMB.

In Vietnam, the study of factors affecting EMB is of interest to some authors, but most studies focus on enterprises (Huynh \& Nguyen, 2019; Huynh, 2020; Nguyen \& Duong, 2020). The research on EMB of banking sector is limited. Typically, Tran and Tran (2020) examined the factors of financial ratios that affect the EMB of 30 Vietnamese commercial banks from 2015 to 2019 and Tran et al. (2020) studied the factors of ownership structure affects EMB of 31 Vietnamese commercial banks from 2005 to 2019. There are currently no previous Vietnamese studies examining the $\mathrm{CG}$ to EMB factors listed banks

\section{Methodology}

Currently, Vietnam has 18 banks listed on the stock exchange of Vietnam. The time series includes 150 samples of these listed banks in the period from 2015 to 2019. The article uses quantitative methods and OLS with Eviews 10.0 software to test the regression model.

On the basis of surveys of experts of Vietnamese commercial banks, combined with some independent variables of previous studies, the article proposes the multivariate regression model is designed as follows:

$$
\begin{aligned}
\mathrm{EMB}= & \beta 0+\beta 1 * \mathrm{SIZE}+\beta 2 * \mathrm{INDE}+\beta 3 * \mathrm{DUAL} \\
& +\beta 4 * \mathrm{FORE}+\beta 5 * \mathrm{AUDI}+\beta 6 * \mathrm{FEMA}+\varepsilon
\end{aligned}
$$

There are several methods of measuring EMB for businesses, but Shen (2016) said that the banking sector has specific business activities, so the measurement criteria are also different. The measurement based on the EMB can be determined by the representative relative to the operation risk or provision expense ratio for credit risk, or the provision expense ratio for bad debt. However, the bad debt problem of Vietnamese banks is alarming in the last five years, so according to some experts of the State bank of Vietnam, EMB is measured on the basis of the provision expense ratio for bad debt is more suitable. Therefore, the article chooses to measure EMB in that term. The formula for determining the provision expense ratio for bad debt is as follows:

$$
R I S K_{-} L L R=\frac{L L R / A S S E T_{T-1}}{\sigma_{L L R / A S S E T_{T-1}}}
$$

Where:

$\mathrm{LLR}_{\mathrm{it}}$ : Provisions for credit losses/ total outstanding loans of the bank (i) at year (t).

ASSET $_{\mathrm{t}-1}$ : Bank's total assets (i) at year (t-1)

$\sigma_{\text {LLR/ASSET }_{t-1}}$ : Standard deviation of LLR/ ASSETt-1 data from 2005 to 2016 , if the data cannot be collected enough, the standard deviation is determined according to the available data.

For the independent variables of $\mathrm{CG}$, the measurement of these variables and their references to previous studies is summarized in Table 1. 
Table 1: Description of independent variables

\begin{tabular}{|c|c|c|c|}
\hline Variable name & Description & Measurement & Previous studies related \\
\hline SIZE & Board size & $\begin{array}{l}\text { Number of Board } \\
\text { members }\end{array}$ & $\begin{array}{l}\text { Olaoye \& Adewumi (2018); Osemene, Adeyele \& } \\
\text { Adinnu (2018); Saiful (2018); Siyanbola et al. (2019) }\end{array}$ \\
\hline INDE & $\begin{array}{l}\text { Independent members } \\
\text { of Board }\end{array}$ & $\begin{array}{l}\text { Rate of independent } \\
\text { members of Board in the } \\
\text { total number of members } \\
\text { of board }\end{array}$ & $\begin{array}{l}\text { Cornett, McNutt \& Tehranian (2009); Li et al. (2017); } \\
\text { Olaoye \& Adewumi (2018); Fitri, Muda \& Badaruddin } \\
\text { (2018); Saiful (2018); Sadjiarto, Monica \& Budiarti } \\
\text { (2019); Siyanbola et al. (2019) }\end{array}$ \\
\hline DUAL & $\begin{array}{l}\text { Board chairperson } \\
\text { duality }\end{array}$ & $\begin{array}{l}\text { Dummy variable, if } \\
\text { there is concurrently } \\
\text { between board chairman } \\
\text { and CEO is } 1 \text { and the } \\
\text { opposite is } 0 .\end{array}$ & Cornett, McNutt \& Tehranian (2009) \\
\hline FORE & $\begin{array}{l}\text { Foreign members of } \\
\text { Board }\end{array}$ & $\begin{array}{l}\text { Rate of foreign members } \\
\text { in the total number of } \\
\text { Board }\end{array}$ & Siyanbola et al. (2019) \\
\hline AUDI & Audit committee & $\begin{array}{l}\text { Dummy variable, if board } \\
\text { is consulted by Big } 4 \\
\text { Auditing company is } 1 \\
\text { and the opposite is } 0 .\end{array}$ & $\begin{array}{l}\text { Cornett, McNutt \& Tehranian (2009); Li et al. (2017); } \\
\text { Olaoye \& Adewumi (2018); Fitri, Muda \& Badaruddin } \\
\text { (2018); Saiful (2018) }\end{array}$ \\
\hline FEMA & $\begin{array}{l}\text { Female members of } \\
\text { Board }\end{array}$ & $\begin{array}{l}\text { Rate of female members } \\
\text { of board in the total } \\
\text { number of Board }\end{array}$ & Osemene, Adeyele \& Adinnu (2018) \\
\hline
\end{tabular}

Table 2: Descriptive statistics

\begin{tabular}{|l|c|c|c|c|c|c|c|}
\hline Variable & EMB & SIZE & INDE & DUAL & FORE & AUDI & FEMA \\
\hline Mean & 3.4108 & 8.1260 & 0.1484 & 0.1526 & 0.1069 & 0.8867 & 0.0502 \\
\hline Maximum & 8.2947 & 9.1732 & 0.4361 & 0.2104 & 0.3000 & 1.0000 & 0.1561 \\
\hline Minimum & 0.3780 & 7.2492 & 0.0000 & 0.0527 & 0.0000 & 0.0000 & 0.0000 \\
\hline Std. Dev. & 0.1069 & 0.4607 & 0.0592 & 0.0108 & 0.0092 & 0.0110 & 0.0094 \\
\hline Observations & 90 & 90 & 90 & 90 & 90 & 90 & 90 \\
\hline
\end{tabular}

Source: Analytical data from EViews 10

\section{Results}

EMB of Vietnamese listed banks has been low for the past five years. The average level is $3.41 \%$, of which the maximum and minimum are $8.29 \%$ and $0.37 \%$, respectively. This level guarantees materiality, so it is acceptable. Furthermore, the standard deviation of EMB is negligible. This shows that Vietnamese listed banks comply with the regulations and strictly enforce the current regulations in the presentation and disclosure of financial statements. For the independent variables, the results indicate that SIZE has an average of 8.1260 members in the Board, of which the maximum is 9.1732 and the minimum is 8.0951. Furthermore, the average ratios of INDE, DUAL, FORE, AUDI and FEMA are 14.84\%; 15.26\%;
$10.69 \% ; 88.67 \%$ and $5.02 \%$, respectively. The statistics of the independent variables related to $\mathrm{CG}$ are consistent with the provisions of the Law on credit institutions (2017) and the Law on enterprises (2020). All independent variables have a negligible standard deviation so there is not much difference in the statistical data of the variables among listed banks.

According to Table 3, the coefficients of the variables have quite good correlation and the level of these coefficients ranges from 0.2106 to 0.5128 . As for the correlation with $\mathrm{EMB}$, the results show that there are two variables inversely correlated with EMB including AUDI and FORE, while the rest are positively related to EMB. These correlation coefficients are less than 0.8 , so there is no multicollinearity phenomenon (Hair et al. 2009). 
Table 3: Correlations

\begin{tabular}{|l|c|c|c|c|c|c|c|}
\hline Variables & EMB & AUDI & INDE & SIZE & FORE & DUAL & FEMA \\
\hline EMB & 1.0000 & & & & & & \\
\hline AUDI & -0.5128 & 1.0000 & & & & & \\
\hline INDE & 0.2667 & 0.2223 & 1.0000 & & & & \\
\hline SIZE & 0.4091 & 0.4319 & 0.2359 & 1.0000 & & & \\
\hline FORE & -0.4738 & 0.4350 & 0.2106 & 0.5326 & 1.0000 & & \\
\hline DUAL & 0.2416 & -0.3275 & -0.2672 & 0.3496 & 0.2821 & 1.0000 & \\
\hline FEMA & 0.3590 & 0.3168 & 0.2841 & 0.3654 & 0.2718 & 0.2638 & 1.0000 \\
\hline
\end{tabular}

Source: Analytical data from EViews 10

Table 4: Coefficients

\begin{tabular}{|l|c|c|c|c|}
\hline Variable & Coefficient & Std. Error & t-Statistic & Prob. \\
\hline C & 0.115119 & 0.002868 & 2.130392 & 0.0000 \\
\hline SIZE & 0.952452 & 0.011652 & 0.956698 & 0.4816 \\
\hline INDE & 0.823672 & 0.013030 & 1.159178 & 0.1650 \\
\hline FORE & -1.268055 & 0.137412 & -2.932544 & 0.0000 \\
\hline AUDI & -1.697138 & 0.113275 & -2.138051 & 0.0000 \\
\hline DUAL & 0.823672 & 0.003030 & 1.059178 & 0.3584 \\
\hline FEMA & 0.903474 & 0.001048 & 1.285314 & 0.1418 \\
\hline R-squared & 0.860221 & Mean dependent var & 3.405789 \\
\hline Adjusted R-squared & 0.729148 & S.D. dependent var & 3.406911 \\
\hline S.E. of regression & 2.706193 & Akaike info criterion & 4.868141 \\
\hline Sum squared resid & 1054.581 & Schwarz criterion & 4.988566 \\
\hline Log likelihood & 359.1106 & Hannan-Quinn criter. & 4.917066 \\
\hline F-statistic & 18.43024 & Durbin-Watson stat & 2.270464 \\
\hline Prob(F-statistic) & 0.000000 & & \\
\hline
\end{tabular}

Table 4 shown that Adjusted R-squared is 0.7291 and it means that $72.91 \%$ of the variation in EMB is explained by the independent variables. This level of explanation is quite high. Furthermore, the probability value (F-statistic) is 0.000 and it is less than 0.05 , so the model guarantees statistical significance. In addition, the value of Durbin-Watson is 2.2705 so it satisfies the condition that $1<\mathrm{d}<3$. This shows that the model has no similar correlation (Hair et al., 2009). Besides, the regression results of the model show that there are two significant variables (with significance levels less than 0.05 ) and these variables have opposite effects with EMB including FORE and AUDI, as follows:

$$
\mathrm{EMB}=0.115-1.268 * \mathrm{FORE}-1.697 * \mathrm{AUDI}
$$

\section{Discussion and Policy Recommendations}

The study results show that there are two variables having opposite effects on EMB, of which AUDI has higher influence than FORE. This result is consistent with the study by Li et al. (2017) and Cornett et al. (2009) for the AUDI variable. This point that the regulations of audit are consistent by the general rules according to international audit standards. However, this result is not consistent with Siyanbola et al. (2019) for the FORE variable. This suggests that the economic conditions and governance of Nigeria may be different from that of Vietnam in recent times.

For the auditing committee (AUDI), in particular the auditing firms of Big4 play an important role to EMB of in 
the banking sector. Because auditors are responsible for the information of the financial statements to the public, so the control will be stricter on regulations. This will reduce EMB of Vietnamese listed banks.

The foreign members of Board (FORE) have an important meaning for Vietnamese listed banks. Foreign members are more likely to comply with legal regulations. It means that they will enforce accounting policies that are consistent with national and international standards. As a result, the foreign members of Board will have their opinions and this will affect more regulatory compliance. Hence, this will reduce EMB of Vietnamese listed banks. This result is also consistent with the trend of the revised Law on credit institutions (2017) and Law on enterprise (2020) allowing foreigner to participate in the Board of the banking sector. This has significantly reduced the EMB of the banking sector over time.

From the above research results, Central bank of Vietnam needs to pay attention and regularly control EMB of the banking sector. Furthermore, Central bank should strict sanctions to ensure that listed banks comply with regulations, accounting policies as well as the presentation and disclosure of financial statements. It contributes to limited EMB to improve the quality of accounting information in the Vietnamese banking sector. In addition, the managers of Vietnamese listed banks needs to raise their awareness and have a longer-term vision to avoid EMB implementation. EMB is beneficial in the short term, but the consequences can last for years and most importantly damage the reputation of listed banks and it also reduces the credibility and trust of stakeholders. In addition, investors need to equip themselves with a solid knowledge of financial analysis to be able to make appropriate economic decisions. Accordingly, investors should pay attention to listed banks with many foreign members participating in the Board and audited by Big4 for authentic information. This ensures more safety and efficiency in business decisions.

\section{Conclusion}

The banking sector plays an important role in the economy. That is the industry that leads the related industries through monetary and financial policies. Therefore, the EMB of the banking sector is always tightly controlled by the safety and trust of the parties. Through survey results of all Vietnamese listed banks between 2015 and 2019, the results show that there are two factors, FORE and AUDI, which negatively affected EMB of Vietnamese listed banks. Therefore, in order to reduce EMB in the banking sector, the managers of listed banks need to raise awareness and responsibility for information users to ensure transparency and rationality. That is the reputation and trust in the Vietnamese banking sector. Central bank of Vietnam should enhance monitoring of disclosure in listed banks. At the same time, Central bank needs to strictly handle EMB cases of listed banks to contribute to the healing of the information environment. This contributes to improving the quality of information in the Vietnamese banking sector to meet the trend of international economic integration.

\section{References}

Akerlof, G. A. (1970). The market for lemons: Quality uncertainty and the market mechanism. The Quarterly Journal of Economics, 84(3), 488-500. https://academic.oup.com/qje/ article-abstract $/ 84 / 3 / 488 / 1896241$ ?redirectedFrom=fulltext

Beneish, M. D. (2001). Earnings Management: A Perspective. Managerial Finance, 27(12), 3-17. https://doi. org/10.1108/03074350110767411

Bruns, W., \& Merchant, K. (1990). The dangerous morality of managing earnings. Management Accounting, 72(1990), 22-25. https://www.hbs.edu/faculty/Pages/item.aspx?num=2605

Chan, K., Menkveld, A. J., \& Yang, Z. (2008). Information Asymmetry and Asset Prices: Evidence from the China Foreign Share Discount. The Journal of Finance, 63(1), 159-196. https://doi.org/10.1111/j.1540-6261.2008.01313.

Cornett, M. M., McNutt, J. J., \& Tehranian, H. (2009). Corporate governance and earnings management at large U.S. bank holding companies. Journal of Corporate Finance, 15(2009), 412-430. http://doi:10.1016/j.jcorpfin.2009.04.003.

Fitri, A., Muda, I., \& Badaruddin. (2018). The Influence of Good Corporate Governance, Leverage, and Profitability on Earning Management with Firm Size as Moderating Variable in the Banking Companies Listed In Indonesia Stock Exchange in the Period of 2012-2016. International Journal of Research \& Review, 5(9), 49-66. https://www.researchgate.net/ publication/328347186

Freeman, R. E. (1984). Strategic management: A stakeholder approach. Boston, MA: Pitman Publisher

Gordon, M. J. (1964). Postulate, Principles and Research in Accounting. The Accounting Review, 39, 251-263. https:// www.scirp.org/(S(czeh2tfqyw2orz553k1w0r45))/reference/ ReferencesPapers.aspx?ReferenceID $=1670584$

Graham, J. R., Harvey, C. R., \& Rajgopal, S. (2005). The economic implications of corporate financial reporting. Journal of Accounting and Economics, 40(2005), 3-73. https://faculty. fuqua.duke.edu/ charvey/Research/Published_Papers/P89_ The_economic_implications.pdf

Hair, J. F., Black, W. C., Babin, B. J., \& Andersom, R. E. (2009). Multivariate Data Analysis. Upper Saddle River, NJ: PrenticeHall International, Inc.

Healy, P. M., \& Wahlen, J. M. (1999). A review of the earnings management literature and its implications for standard setting. Accounting Horizons, 13(4), 365-383. https://doi.org/10.2308/ acch.1999.13.4.365

Hillman, A. J., \& Dalziel, T. (2003). Boards of Directors and Firm Performance: Integrating Agency and Resource Dependence 
Perspectives. The Academy of Management Review, 28(3), 383396. http://DOI: $10.2307 / 30040728$

Huynh, Q. L., \& Nguyen, V. N. (2019). The Effect of Prior Financial Performance on Organizational Reputation and Earnings Management. Journal of Asian Finance, Economics and Business, 6(4), 75-81. http://doi:10.13106/jafeb.2019.vol6. no4.75

Huynh, Q. L. (2020). A Triple of Corporate Governance, Social Responsibility and Earnings Management. Journal of Asian Finance, Economics and Business, 7(3), 29-40. http:// doi:10.13106/jafeb.2020.vol7.no3.29

Jensen, M. C., \& Meckling, W. H. (1976). The theory of the firm: Managerial behavior, agency costs and ownership structure. Journal of Financial Economics, 3(4), 305-360. https://www. sciencedirect.com/science/article/pii/0304405X7690026X

Leuz, C., Nanda, D., \& Wysocky, P. D. (2003). Earnings management and investor protection: an international comparison. Journal of Financial Economics, 69(2003), 505-527. http:// doi:10.1016/ S0304-405X(03)00121-1

Li, Y., Nie, W., Xiang, E., \& Djajadikerta, H. G. (2017). Can banks identify firms' real earnings management? Evidence from China. Finance Research Letters, 25(C), 23-29. http://doi: 10.1016/j.frl.2017.10.005

National Assembly of Vietnam. (2017). Law on credit institutions. Vietnam: Hanoi Publishing House.

National Assembly of Vietnam. (2020). Law on enterprises. Vietnam: Hanoi Publishing House.

Nguyen, A. H., \& Duong, C. T. (2020). Provincial Governance Quality and Earnings Management: Empirical Evidence from Vietnam. Journal of Asian Finance, Economics and Business, 7(2), 43-52. http://doi:10.13106/jafeb.2020.vol7.no2.43

Nguyen, H., \& Phan, H. (2020). A heavy penalty is imposed on listed companies for making false financial statements, seen from CII's case. Securities Investment Magazine, 9(2020), 1-3. https://tinnhanhchungkhoan.vn/phat-nang-doanh-nghiepniem-yet-lap-bao-cao-tai-chinh-sai-nhin-tu-truong-hop-cuacii-post249278.html

OECD. (2015). G20/OECD Principles of Corporate Governance. Paris: OECD Publishing.

Olaoye, F. O., \& Adewumi, A. A. (2018). Corporate Governance and Earning Management of Deposit Money Banks in Nigeria. International Journal of Scientific \& Engineering Research, 9(7), 184-199. https://www.ijser.org/researchpaper
Osemene, O. F., Adeyele, J. S., \& Adinnu, P. (2018). The Impact Of The Ownership Structure And Board Characteristics On Earnings Management In Nigeria's Listed Deposit Money Banks. Economic Horizons, 20(3), 209-220. http://doi:10.5937/ ekonhor1803215O

Roychowdhury, S. (2006). Earnings management through real activities manipulation. Journal of Accounting and Economics, 42(2006), 335-370. http://doi:10.1016/j.jacceco.2006.01.002

Sadjiarto, A., Monica, C. C., \& Budiarti, W. R. (2019). Ownership Structure and Earnings Management in Indonesian Listed Banks. Journal of Economics and Business, 2(2), 261-272. http://DOI: 10.31014/aior.1992.02.02.85

Roychowdhury, S. (2006). Earnings management through real activities manipulation. Journal of Accounting and Economics, 42(2006), 662-667. https://doi.org/10.2991/agc-18.2019.99

Schipper, K. (1989). Commentary on earnings management. Accounting Horizons, 3(4), 91-102. http://connection. ebscohost.com/c/articles/4816073/commentary-earningsmanagement

Scott, W. R. (2009). Financial Accounting Theory ( $5^{\text {th }}$ ed.). Canada: Pearson Education.

Shen, L. (2016). Research on Industry Competition, Ownership Structure and Earnings Management: Empirical Analysis based on Listed Bank. International Journal of Smart Home, 10(3), 221-230. http:// DOI: 10.14257/ijsh.2016.10.3.31

Siyanbola, T. T., Ogbebor, P. I., Okeke, O. C., \& Okunade, R. A. (2019). Corporate Governance And Reported Earning Quality In Deposit Money Banks In Nigeria. International Journal of Business and Management Review, 7(5), 26-37. https://www. eajournals.org/wp-content/uploads/

Tangjitprom, N. (2013). The Role of Corporate Governance in Reducing the Negative Effect of Earnings Management. International Journal of Economics and Finance, 5(3), 213220. http:// DOI:10.5539/ijef.v5n3p213

Tran, Q. T., Ly, H. A., \& Nguyen, N. K. D. (2020). Relationship between Ownership Structures and Earnings Management Behavior in Vietnamese Commercial Banks. Journal of Asian Finance, Economics and Business, 7(9), 401-407. http:// doi:10.13106/jafeb.2020.vol7.no9.401

Tran, Q. T., \& Tran, N. A. T. (2020). Influence of financial indicators on earnings management behavior: evidence from Vietnamese commercial banks. Banks and Bank Systems, 15(2),167-176. http://doi:10.21511/bbs.15(2).2020.15 